\title{
Yield, Crude Protein, and Chemical Composition of Five Napier Grass Cultivars on the Northwestern Coastal Plains of Puerto Rico ${ }^{1}$
}

\author{
J. Vélez-Santiago, J. A. Arroyo-Aguilú, and S. Torres-Rivera ${ }^{2,3}$

\section{ABSTRACT}

Five Napier grass cultivars (Pennisetum purpureum Schum.) were evaluated under cutting management on a Bayamón sandy loam soil on the northwestern coastal plains of Puerto Rico for a period of 2.05 years without irrigation. Grasses received a high input of fertilizer $(4,484 \mathrm{~kg} / \mathrm{ha} / \mathrm{yr})$ and were harvested every 52 days. Mean dry forage yield for cultivars PRPI 13079, 7350 , Merker, 13078 , and 532 were $46755,45449,39439,38816$, and 37581 $\mathrm{kg} / \mathrm{ha} / \mathrm{yr}$, respectively. Cultivars 13079 and 7350 had similar dry forage yields, which were significantly $(P<.05)$ higher than those of the remaining cultivars. Cultivar 7350 was the highest crude protein yielder, with $5413 \mathrm{~kg} /$ ha/ $\mathrm{yr}$. Mean crude protein, P, K, Ca, and Mg contents for the 5 cultivars were $11.44, .37,2.56, .31$, and $.34 \%$, respectively. Leaf/stem ratios for all cultivars ranged from a maximum of 60 to a minimum of $52 \%$.

Cultivars 13079 and 7350 are the most outstanding grasses for this region of Puerto Rico. Cultivars 13078 and 532 are recommended as substitutes for the Merker cultivar. However, cultivar 13078 yields can be adversely affected by prolonged droughts.

\section{INTRODUCTION}

The Merker cultivar of Napier grass (Pennisetum purpureum Schum.) was introduced to Puerto Rico from Mississippi by the University of Puerto Rico Agricultural Experiment Station in 1934. Since then, it has been used as a soilage crop, especially on the northern and northwestern coastal plains and other regions of the Island. An estimated 500 ha of this grass are grown for soilage in Puerto Rico. ${ }^{4}$ Although it has been studied extensively in other aspects $(1,2,3,4,5,6,8,11,13,15,16,17,18)$, little research has been conducted to compare the potential of the Merker cultivar with recent Napier introductions.

Recently, Vélez-Santiago and Arroyo-Aguilú (14) reported that four Napier cultivars (PRPI 7350, 7353, 13078, and 13079) were superior to the Merker cultivar in the humid mountainous region of Puerto Rico when harvested at 45- and 60-day intervals throughout the year. They

\footnotetext{
${ }^{1}$ Manuscript submitted to Editorial Board December 9, 1982.

${ }^{2}$ Associate Agronomist, Corozal Substation; Nutritionist, Animal Industry Department; and Research Technician, Corozal Substation, Agricultural Experiment Station, Mayagüez Campus, University of Puerto Rico, Río Piedras, P. R., respectively.

${ }^{3}$ The authors acknowledge the valuable cooperation of Mr. Ramón Talavera for providing his farm and most of the field labor. Appreciation is also extended to Mr. David Jiménez, Forage Specialist, Agricultural Extension Service, University of Puerto Rico, for his assistance.

${ }^{4}$ Jiménez, D., 1981. Personal communication.
} 
reported also that Napier cultivars 13078 and 13079 outyielded the Merker cultivar during the season of short, cool days.

In this study, green forage (GF), dry forage (DF), and crude protein (CP) yields and dry matter (DM), P, K, Ca, and $\mathrm{Mg}$ contents of the Merker cultivar were compared with those of four selected Napier accessions, both on a year basis and during the cool days of short photoperiod in the northwestern coastal plain of Puerto Rico.

\section{MATERIALS AND METHODS}

The experiment was conducted on a private farm in Hatillo, Puerto Rico. The soil is a deep, red, well-drained, acid, sandy loam (Typic Haplorthox) of the Bayamón series, considered to be of medium natural fertility.

The following tabulation identifies the five cultivars:

$\begin{array}{cccl}\text { USDA PI }^{5} & \underline{\text { PR PI }^{6}} & \text { Other } & \begin{array}{l}\text { Relative } \\ \text { leaf width }\end{array} \\ 285303 & 13079 & & \text { Medium } \\ - & 7350 & & \text { Narrow } \\ - & - & \text { Merker } & \text { Medium } \\ 300086 & 13078 & & \text { Broad } \\ - & 532^{7} & & \text { Medium }\end{array}$

The grasses were subjected to a general harvest February 16, 1977, and thereafter GF yields were measured at 50-day harvest intervals for a 2.05year period. All cultivars, except 532, were previously evaluated at 30-, 45-, and 60-day harvest intervals in the mountainous region of Puerto Rico (14).

Fertilization was at the rate of $4484 \mathrm{~kg} / \mathrm{ha} / \mathrm{yr}$, divided into 7 equal applications. Lime was applied, according to the method of Riera (10), at planting and after 1 year, at a rate of $2242 \mathrm{~kg} / \mathrm{ha} / \mathrm{yr}$, to maintain soil $\mathrm{pH}$ at approximately 5.5. No irrigation was applied during the course of the study.

The forage from all plots was hand cut every 50 days at approximately $8 \mathrm{~cm}$ above ground and immediately weighed. On three occasions, leaf/ stem ratio was also determined, on the basis of 30 stems selected at random from each plot. Grass samples per plot were obtained, dried at $55^{\circ} \mathrm{C}$ in a forced-air oven, and ground in a Wiley mill ${ }^{8}$ to pass through a

${ }^{5}$ United States Department of Agriculture plant introduction number.

${ }^{6}$ University of Puerto Rico Agricultural Experiment Station plant introduction number.

${ }^{7}$ Agronomic Center for Research and Teaching, Turrialba, Costa Rica, plant introduction number.

${ }^{8}$ Trade names in this publication are used only to provide specific information. Mention of a trade name does not constitute a warranty of equipment or materials by the Agricultural, Experiment Station of the University of Puerto Rico, nor is this mention a statement of preference over other equipment or materials. 
1-mm screen. Samples were composited by replications for further chemical analyses. Each cultivar was analyzed for total $N$ with a Technicon auto-analyzer during the following periods: February 17, 1977, to February 2, 1978; and September 2, 1977, to February 2, 1978. Samples from February 17, 1977, to March 8, 1979, were analyzed for total N, P and K (9) and for $\mathrm{Ca}$ and $\mathrm{Mg}(7)$ contents. $\mathrm{CP}$ was calculated as $\% \mathrm{~N} \times 6.25$.

The data from February 17, 1977, to February 2, 1978 (350 days); September 2, 1977, to February 2, 1978, (152 days); and February 17, 1977, to March 8, 1979 (748 days) for GF, DF, and CP yields and for DM contents were subjected to analyses of variance and Duncan's multiple range test (12).

TABLE 1.-Mean green forage, dry forage, and crude protein yields and dry matter content of 5 Pennisetum cultivars during the periods of short, cool days (152 days) and of 350 days

\begin{tabular}{|c|c|c|c|c|}
\hline Identification & $\begin{array}{c}\text { Green } \\
\text { forage } \\
\text { yield }\end{array}$ & $\begin{array}{c}\text { Dry } \\
\text { matter } \\
\text { content }\end{array}$ & $\begin{array}{c}\text { Dry } \\
\text { forage } \\
\text { yield }\end{array}$ & $\begin{array}{l}\text { Crude } \\
\text { protein } \\
\text { yield }\end{array}$ \\
\hline & $\mathrm{kg} / \mathrm{ha}$ & $\%$ & $k g / h a$ & $k g / h a$ \\
\hline & \multicolumn{4}{|c|}{ Period of short cool days (152 days) } \\
\hline 13079 & $94,475 a^{1}$ & $19.46 \mathrm{a}$ & 18,311 a & $1,870 \mathrm{ab}$ \\
\hline 7350 & 91,763 a & $19.19 \mathrm{a}$ & $18,007 \mathrm{a}$ & 2,147 a \\
\hline Merker & 83,493 a & $17.92 \mathrm{ab}$ & $15,329 \mathrm{~b}$ & $1,881 \mathrm{ab}$ \\
\hline 13078 & $91,578 \mathrm{a}$ & $16.73 \mathrm{~b}$ & $15,326 \mathrm{~b}$ & $1,690 \mathrm{~b}$ \\
\hline 532 & 84,243 a & $16.82 \mathrm{~b}$ & $14,373 \mathrm{~b}$ & $1,686 \mathrm{~b}$ \\
\hline \multirow[t]{2}{*}{ Mean } & 89,109 & 18.02 & 16,269 & 1,855 \\
\hline & \multicolumn{4}{|c|}{ Period of 350 days } \\
\hline 13079 & $312,023 \mathrm{a}$ & $16.79 \mathrm{a}$ & 49,630 a & $4,945 \mathrm{a}$ \\
\hline 7350 & 313,275 a & $15.73 \mathrm{~b}$ & $46,189 \mathrm{ab}$ & $5,313 \mathrm{a}$ \\
\hline Merker & $296,044 \mathrm{ab}$ & $15.30 \mathrm{~b}$ & $42,393 \mathrm{bc}$ & $4,994 \mathrm{a}$ \\
\hline 13078 & $269,792 \mathrm{~b}$ & $15.63 \mathrm{~b}$ & $40,566 \mathrm{c}$ & 4,410 a \\
\hline 532 & $274,722 \mathrm{ab}$ & $14.89 \mathrm{~b}$ & $39,053 \mathrm{c}$ & $4,436 \mathrm{a}$ \\
\hline Mean & 293,171 & 15.67 & 43,566 & 4,820 \\
\hline
\end{tabular}

${ }^{1}$ Means in the same column followed by one or more letters in common do not differ significantly at the $5-\%$ probability level.

\section{RESULTS AND DISCUSSION}

The period of short cool days was defined as the 152-day period from September 2, 1977, to February 2, 1978. Table 1 shows yields during this period. No significant differences in GF yields were obtained between cultivars. DM contents for cultivars 13079 and 7350 were significantly (P $=.05$ ) higher than those of cultivars 13078 and 532. The former also outyielded the other three cultivars in DF. Vélez-Santiago and ArroyoAguilú (14) reported similar observations on DF yields for cultivar 13079 during the period of short cool days in the mountainous region of Puerto 
TABLE 2.-Mean yields and dry matter, crude protein, and mineral contents of 5 Pennisetum cultivars during a 2-year period

\begin{tabular}{cccccccccc}
\hline Identification & $\begin{array}{c}\text { Green } \\
\text { forage } \\
\text { yield }\end{array}$ & $\begin{array}{c}\text { Dry } \\
\text { matter } \\
\text { content }\end{array}$ & $\begin{array}{c}\text { Dry } \\
\text { forage } \\
\text { yield }\end{array}$ & $\begin{array}{c}\text { Crude } \\
\text { protein } \\
\text { yield }\end{array}$ & $\begin{array}{c}\text { Crude } \\
\text { protein }\end{array}$ & Phosphorus & Potassium & Calcium & Magnesium \\
\hline & $k g / h a / y$ & $\%$ & $k g / h a / y$ & $k g / h a / y$ & $\%$ & $\%$ & $\%$ & $\%$ \\
13079 & $281,342 \mathrm{a}$ & $17.57 \mathrm{a}$ & $46,755 \mathrm{a}$ & $4,759 \mathrm{~b}$ & 10.19 & 0.38 & 2.08 & 0.22 & 0.39 \\
7350 & $294,744 \mathrm{a}$ & $16.36 \mathrm{~b}$ & $45,449 \mathrm{a}$ & $5,413 \mathrm{a}$ & 11.94 & 0.35 & 2.75 & 0.38 & 0.33 \\
Merker & $265,394 \mathrm{~b}$ & $16.15 \mathrm{~b}$ & $39,439 \mathrm{~b}$ & $4,744 \mathrm{~b}$ & 12.00 & 0.34 & 2.93 & 0.31 & 0.30 \\
13078 & $247,048 \mathrm{~b}$ & $16.13 \mathrm{~b}$ & $38,816 \mathrm{~b}$ & $4,251 \mathrm{~b}$ & 11.00 & 0.36 & 2.55 & 0.31 \\
532 & $247,762 \mathrm{~b}$ & $15.81 \mathrm{~b}$ & $37,581 \mathrm{~b}$ & $4,502 \mathrm{~b}$ & 12.06 & 0.40 & 2.50 & 0.32 & 0.30 \\
Mean & 267,258 & 16.40 & 41,608 & 4,734 & 11.44 & 0.37 & 2.56 & 0.31 & 0.34 \\
\hline
\end{tabular}

${ }^{1}$ Means in the same column followed by one or more letters in common do not differ significantly at the 5-\% probability level. 
Rico. Only cultivar 7350 was significantly $(\mathrm{P}=.05)$ superior to cultivars 13078 and 532 in CP yields.

The 350-day data indicated that cultivar 7350 produced highest CP yields, while cultivar 13079 presented highest DM content and DF yield. These two cultivars were practically equal in GF yield. DF yields and DM contents of cultivar 13079, but not those of 7350 , were superior ( $P$ $=.05)$ to those of the Merker cultivar. The latter was not significantly inferior in GF yield. Both cultivars 13078 and 532 were inferior ( $\mathrm{P}=.05)$ to the two leading cultivars in DF yield, but not in CP yield (table 1). The period of short cool days which constituted $41 \%$ of this phase of the experiment contributed $30 \%, 37 \%$, and $38 \%$ of the 350 -day $\mathrm{GF}, \mathrm{DF}$, and $\mathrm{CP}$ yields, respectively.

Table 2 shows the GF, DF, and CP yields and DM, CP, P, K, Ca, and $\mathrm{Mg}$ contents of the grasses throughout the 2-year period. The highest GF

TABLE 3.-Proportion of leaf blades (percent of dry-weight basis) for 5 Pennisetum cultivars harvested every 50 days

\begin{tabular}{lcccccccc}
\hline \multirow{2}{*}{ Harvest date } & Day & \multicolumn{5}{c}{ Leaf/stem ratio $^{1,2}$} & Mean & $\begin{array}{c}\text { Rainfall } \\
\text { per } \\
\text { period }\end{array}$ \\
\cline { 3 - 6 } & & 13079 & 7350 & Merker & 13078 & 532 & & $\mathrm{~mm}$ \\
\hline 12-13-77-2-2-78 & 52 & 57 & 53 & 61 & 56 & 56 & 57 & 100 \\
$5-11-78-6-29-78$ & 50 & 59 & 63 & 57 & 60 & 60 & 60 & 323 \\
$6-30-78-8-21-78$ & 53 & 50 & 49 & 48 & 57 & 57 & 52 & 151 \\
Mean & 51 & 55 & 55 & 55 & 58 & 58 & 56 & \\
\hline
\end{tabular}

${ }^{1}$ Mean values of 4 replicates per grass.

${ }^{2}$ Stem includes the sheath.

and DF yields were obtained with cultivars 13079 and 7350, respectively, being significantly $(\mathrm{P}=.05)$ different from the other three cultivars. Cultivar 7350 produced the highest $\mathrm{CP}$ yield, significantly $(\mathrm{P}=.05)$ different from all other cultivars. The other cultivars were rather similar in CP yields.

Cultivar 13079 had the highest DM content, significantly $(\mathrm{P}=.05)$ different from all the others, but the lowest $\mathrm{CP}$ content. This same negative relationship has been observed in other studies (14). Cultivar 13079 also contained the lowest $\mathrm{K}$ and $\mathrm{Ca}$ contents, while the other cultivars differed little in CP, P, K, Ca, and Mg contents. Similar mineral contents were reported by Vicente-Chandler et al. (17) for the Merker cultivar when harvested every 40 days.

The leaf/stem ratio between cultivars was very similar and varied from a maximum of 60 to a minimum of $52 \%$ during different months of the year (table 3). 
The yields of these Napier cultivars harvested every 50 days, with 4484 $\mathrm{kg}$ of 15-5-10 fertilizer/ha/yr remained high throughout most of the year except during the period of short cool days when growth was slower. It is recommended that the harvest interval be lengthened in order to increase yields during this part of the year (18). Except during the period of slow

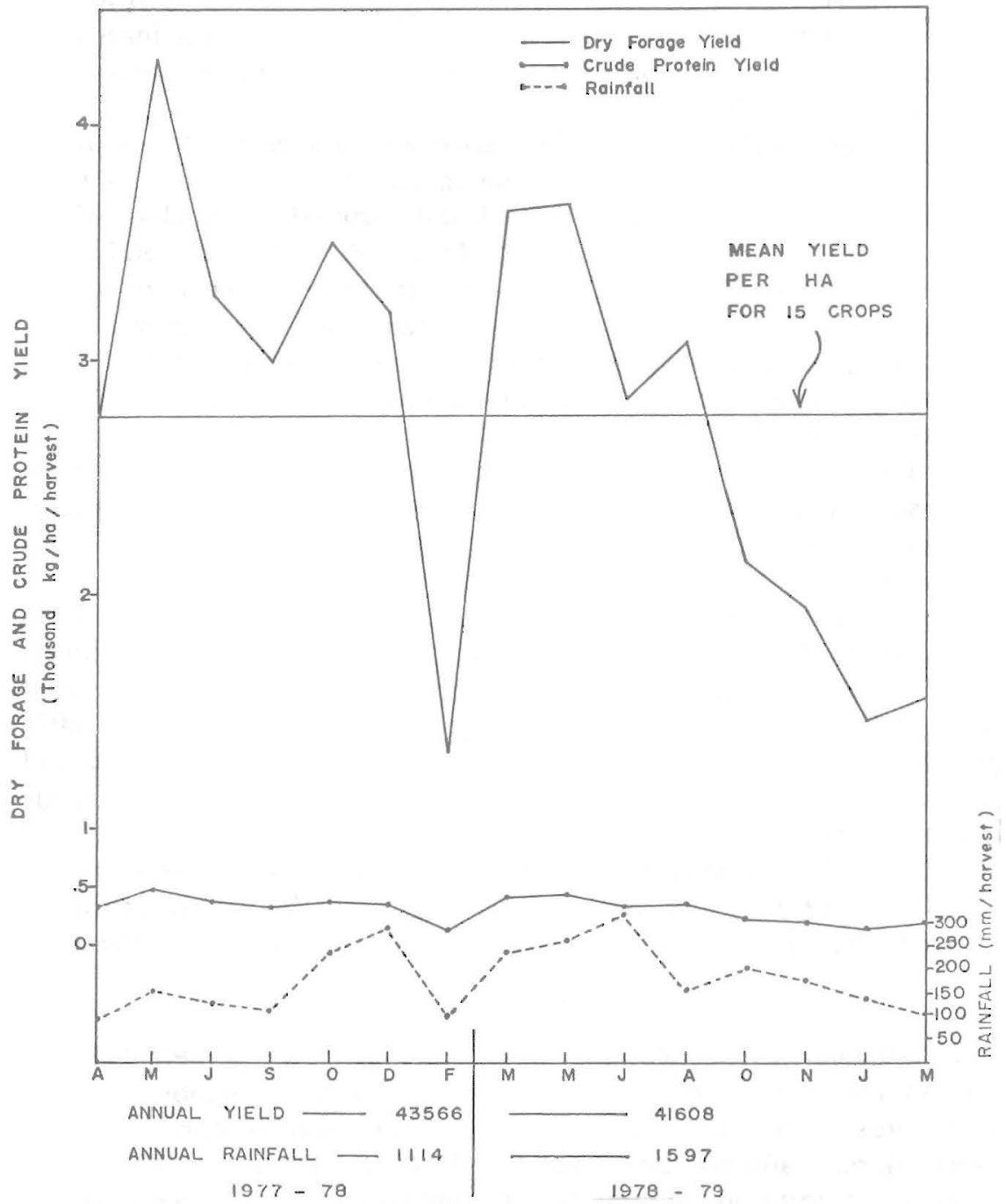

FIG. 1.-Mean dry forage and crude protein yields, and rainfall distribution-5 Napier cultivars harvested every 50 days from April 6, 1977 to March 8, 1979 at Hatillo, Puerto Rico. 
growth, plant height at harvest generally ranged from 1.53 to $1.82 \mathrm{~m}$. Weeds were not a problem, in contrast to the situation which prevailed when the grasses were harvested every 30 -days in the mountainous region of Puerto Rico (14). Thus, the grasses maintained solid stands throughout the 2 years of the experiment.

The annual excess of GF yield of cultivar 13079 over that of the Merker cultivar (15948 kg/ha/yr) would be enough to supply the theoretical feed requirement for 0.45 animal-year/ha (227 kg liveweight), assuming a daily intake equivalent to $15.67 \%$ of liveweight and $20 \%$ of wasted forage in a feeding operation (18).

Figure 1 shows that forage yields varied widely during different mo of the year. DF yields were below the mean of the 15 harvests from December 13, 1977 to February 2, 1978, and during the final phase of the experiment from October 9, 1978, to March 8, 1979. Apparently, the shorter and cooler days during the latter part of the first year and during the first 3 mo of the second year contributed to a reduced growth rate, although yields of cultivars 13079 and 7350 were affected less than those of other cultivars (table 1). A similar seasonal pattern of DF yields was reported by Vicente-Chandler et al. (17) for the Merker cultivar.

At the end of the trial, the soil had a $\mathrm{pH}$ of 4.6 , in spite of the lime application at planting and again at the beginning of the second year of the experiment. This is in agreement with the statement of VicenteChandler et al. (18), that quantities of $\mathrm{N}$ as high as $840 \mathrm{~kg} / \mathrm{ha} / \mathrm{yr}$ have a strong effect in lowering soil pH. Thus, the need to apply at least 2242 $\mathrm{kg} / \mathrm{ha} / \mathrm{yr}$ of calcium carbonate to maintain optimum soil $\mathrm{pH}$ was evident. Rainfall was adequate for rapid grass growth, except during the period from December 14, 1977, to February 2, 1978, when cultivar 13078 presented symptoms of water stress. This cultivar has broad leaves and thick stems. Therefore, its water requirements may be higher than those of other cultivars.

Cultivars 13079 and 7350 excel over the remaining cultivars. Cultivars 13078 and 532 were comparable to the Merker cultivar, except during prolonged drought, when cultivar 13078 yields were adversely affected.

\section{RESUMEN}

Se evaluaron cinco cultivares de la gramínea de corte elefante ( $P$ ennisetum purpureum Schum.) durante 748 días en los llanos húmedos costaneros del noroeste de Puerto Rico. Estas se abonaron a razón de $4484 \mathrm{~kg} / \mathrm{ha}$ y año con un análisis $15-5-10$, distribuido en siete partes iguales y se cortaron cada 50 días. El suelo es del tipo Bayamón lómico arenoso, considerado de mediana fertilidad. Se determinaron los rendimientos de forraje verde y seco y de proteína bruta y los contenidos de materia seca, proteína bruta, fósforo, potasio, calcio y magnesio. 
Los rendimientos de las cultivares 13079 y 7350 fueron mayores que los de la cultivar Merker, generalmente utilizada por los ganaderos de la región, tanto por su rendimiento en los meses fríos como durante el año entero. Los rendimientos de forraje seco de las cultivares 13079,7350 , Merker, 13078 y 532, respectivamente fueron de 46755, 45449, 39439, 38816 y $37581 \mathrm{~kg} /$ ha y año. Las cultivares 13079 y 7350 produjeron rendimientos similares de forraje seco y sobrepasaron significativamente $(P=.05)$ las restantes cultivares. La cultivar 7350 produjo el rendimiento mayor de proteína bruta, que fue de $5413 \mathrm{~kg} / \mathrm{ha}$ y año. Los contenidos medios de proteína bruta, fósforo, potasio, calcio y magnesio fueron $11.44, .37,2.56, .31$ y .34\%, respectivamente. La razón de hoja a caña fue bastante similar en las cinco cultivares y varió de un máximo de 60 a un mínimo de $52 \%$.

Se concluye que, cosechar las gramíneas Napier cada 50 días fue apropiado para la mayor parte del año, excepto en los meses fríos en que los yerbas no crecieron lo suficiente para producir buenos rendimientos. Se sugiere cortarlas a un intervalo más largo durante esta época del año con el fin de conseguir mejores rendimientos.

Se recomiendan las cultivares 13079 y 7350 para corte en vez de la cultivar Merker para esta zona de Puerto Rico. Las cultivares 13078 y 532 son recomendables también como posibles substitutas de la cultivar Merker. Sin embargo, la cultivar 13078 sufre más los efectos de sequías prolongadas.

\section{LITERATURE CITED}

1. Abruña, F., Vicente-Chandler, J., and Pearson, R. W., 1964. Effects of liming on yields and composition of heavily fertilized grasses and on soil properties under humid tropical conditions. Proc. Soil Sci. Soc. Am. 28 (5): 657-61.

2. Alexander, A. G. and Spain, G. L., 1970. Isolation and properties of Napier grass Bamylase. J. Agric. Univ. P. R. 54 (4): 640-56.

3. Boneta-García, E., 1954. Nuevas yerbas forrajeras para Puerto Rico, Esta. Exp. Agric. Univ. P. R. Publ. Misc. 12.

4. Caro-Costas, R. and Vicente-Chandler, J., 1961. Effects of two cutting heights on yields of five tropical grasses, J. Agric. Univ. P. R. 45 (1); 46-9.

5. - - and-—, 1961. Cutting height strongly affects yields of tropical grasses, Agron. J. 53 (1): 59-60.

6. - - and- - 1972. Effect of heavy rates of fertilization on beef production and carrying capacity of Napier grass pastures over 5 consecutive years of grazing under humid tropical conditions, J. Agric. Univ. P. R. 56 (3): 223-7.

7. Greweling, T., 1962. An extraction procedure for the determination of total calcium, magnesium, and potassium in plant tissue, J. Agric. Food Chem. 10: 138-40.

8. Oakes, A. J., 1959. Germination of elephant grass (Pennisetum purpureum Schum.), J. Agric. Univ. P. R. 43 (2): 140. (Res. Note).

9. Riera, A., 1955. The method of foliar diagnosis as applied to sugarcane, II, The chemical analyses of sugarcane-leaf samples, Univ. P. R. Agric. Exp. Stn. Bull. 123.

10. - - 1946. Laboratory recommendation of lime to an acid soil checks with expected $\mathrm{pH}$ changes, J. Agric. Univ. P. R. 30 (3): 184-5. 
11. Rivera-Brenes, L., Arroyo, J. A., Cestero, H., and Sierra, A., 1961. Palatability tests on giant Pangola (Digitaria valida Stent) and Signal grass (Brachiaria brizantha) as compared with Napier (Merker) grass (Pennisetum purpureum), J. Agric. Univ. P. R. 45 (3): 147-50,

12. Snedecor, G. W. and Cochran, W. G., 1967. Statistical methods, 6th ed, The Iowa State Univ. Press, Ames, Iowa.

13. Spain, G. L. and Vélez-Santiago, J., 1973. Napier grass harvest readiness, J. Agric. Univ. P. R. 57 (4): 300-6.

14. Vélez-Santiago, J. and Arroyo-Aguilú, J. A., 1981. Effect of three harvest intervals on yield and nutritive value of seven Napier grass cultivars, J. Agric. Univ. P. R. 65 (2): $129-37$.

15. Vicente-Chandler, J. and Figarella, J., 1962. Effects of five nitrogen sources on yield and composition of Napier grass, J. Agric. Univ. P. R. 46 (2): 102-6.

16. —- Silva, S., and Figarella, J., 1959. The effect of nitrogen fertilization and frequency of cutting on the yield and composition of three tropical grasses, Agron. J. 51 (4): 202-6.

17. —_, - - and ——, 1959. Effects of nitrogen fertilization and frequency of cutting on the yield and composition of Napier grass in Puerto Rico, J. Agric. Univ, P. R. 43 (4): 215-27.

18. —- Abruña, F., Caro-Costas, R., Figarella, J., Silva, S., and Pearson, R. W., 1974. Intensive Grassland Management in the Humid Tropics of Puerto Rico, Agric. Exp. Stn. Univ. P. R., Bull. 233. 